\title{
PRESCRIBED FIRE IN GRASSLAND BUTTERFLY HABITAT: TARGETING WEATHER AND FUEL CONDITIONS TO REDUCE SOIL TEMPERATURES AND BURN SEVERITY
}

\author{
Kathryn C. Hill*, Jonathan D. Bakker, and Peter W. Dunwiddie \\ School of Environmental and Forest Sciences, University of Washington, \\ Box 354115, Seattle, Washington 98195, USA
}

*Corresponding author: Tel.: +1-206-769-2036; e-mail: khill@cnlm.org

\begin{abstract}
Prescribed burning is a primary tool for habitat restoration and management in fire-adapted grasslands. Concerns about detrimental effects of burning on butterfly populations, however, can inhibit implementation of treatments. Burning in cool and humid conditions is likely to result in lowered soil temperatures and to produce patches of low burn severity, both of which would enhance survival of butterfly larvae at or near the soil surface. In this study, we burned 20 experimental plots in South Puget Sound, Washington, USA, prairies across a range of weather and fuel conditions to address the potential for producing these outcomes. Risk to diapausing butterfly larvae, assessed by measuring subsurface soil temperatures and heat dosages, was lower when air temperature was less than $26^{\circ} \mathrm{C}$ and dead fuel moisture was greater than $9 \%$. The likelihood that unburned or low-severity patches would be left was affected by dead fuel moisture, but also required pre-existing fuel discontinuities. Burns conducted in the morning hours during the summer drought season (the main prescribed-fire season in this system) were cooler and had low-
\end{abstract}

RESUMEN

Las quemas prescritas son una herramienta básica para la restauración y el manejo de ecosistemas de pastizales adaptados a fuegos periódicos. La preocupación sobre los efectos perjudiciales de estas quemas sobre las poblaciones de mariposas, pueden inhibir la implementación de estos tratamientos. Las quemas en condiciones frías y húmedas es probable que resulten en bajas temperaturas del suelo y produzcan parches de baja severidad, lo que redundará en un aumento en la supervivencia de larvas de mariposas cercanas a, o inmediatamente sobre, la superficie del suelo. En este estudio, quemamos en 20 parcelas experimentales en las praderas de South Puget Sound, en el estado de Washington, EEUU, a través de un rango de condiciones meteorológicas y de combustibles para determinar el potencial para producir estos resultados. El riesgo de producir diapausas en las larvas de mariposas, determinado mediante la medición de temperaturas sub-superficiales y el dosaje del calor, fue menor cuando la temperatura del aire estuvo por debajo de $\operatorname{los} 26^{\circ} \mathrm{C}$ y el contenido de humedad del combustible muerto fue mayor al 9\%. La probabilidad de que aparezcan parches no quemados o quemados a baja severidad fue afectada por la humedad del combustible muerto, pero también requirieron de la pre-existencia de parches de combustible discontinuos. Las quemas conducidas en horas de la mañana durante la estación seca del verano (la época recomendada de prescripción de quemas en este sis- 
er severities. This research increases our understanding of how fine fuel moisture and fuel continuity during grassland burning can affect fire intensity, severity, and spread. It also provides support for burning earlier in the day as a way to increase burn heterogeneity and has allowed us to create recommendations for burning in sensitive butterfly habitat. tema) fueron más frías y tuvieron menor severidad. Esta investigación incrementa nuestra comprensión de cómo el combustible fino y su continuidad durante una quema de pastizal puede incrementar la intensidad, severidad, y velocidad de propagación del fuego. También provee de evidencias para quemar temprano en la mañana e incrementar la heterogeneidad de la quema, y nos permitió realizar recomendaciones para quemar en áreas sensibles en hábitats de mariposas.

Keywords: butterflies, fuel moisture, lethal heat dosage, prescribed fire, severity, soil temperatures, western Washington

Citation: Hill, K.C., J.D. Bakker, and P.W. Dunwiddie. 2017. Prescribed fire in grassland butterfly habitat: targeting weather and fuel conditions to reduce soil temperatures and burn severity. Fire Ecology 13(3): 24-41. doi: 10.4996/fireecology.130302441

\section{INTRODUCTION}

Prescribed burning is one of the primary tools for fuels reduction, agricultural residue consumption, and habitat restoration across ecosystems; in the United States, almost 1.2 million hectares of land were intentionally burned in 2015 (National Interagency Fire Center 2016). In fire-adapted grassland and shrubland ecosystems, prescribed fires are used for habitat restoration and endangered species conservation (Hamman et al. 2011). Concerns about potentially detrimental effects of burning on diapausing butterfly larvae near the soil surface, as well as other ground-dwelling arthropods and bryophyte and lichen communities, however, can sometimes inhibit the implementation of restoration treatments (Fimbel 2004, Hamman et al. 2011, Schultz et al. 2011, Calabria et al. 2016). These organisms are more likely to survive a fire in areas that experience lower soil temperatures during the burn or in unburned and low-severity patches (Bradstock et al. 2005, New 2014). Conducting prescribed fires during cooler and more humid weather can help promote these conditions (Knapp and Keeley 2006). This analysis focuses on the relationship between weather and fuel conditions and several response variables that serve as metrics of the risk to fire-sensitive organisms near the soil surface during prescribed fires.

In South Puget Sound, Washington, USA, prairies, quality habitat for several at-risk, threatened, or endangered butterfly species is composed of short-statured herbaceous vegetation with a mix of open spaces for basking and oviposition access (Schultz et al. 2011). Creation and maintenance of this type of vegetation structure is possible through the application of prescribed fire at regular intervals, combined with herbicide treatments for invasive grasses and seeding of fire-adapted native species (Hamman et al. 2011). The risk of fire to invertebrate populations, however, limits the conditions under which prescribed burning can occur. While a certain level of mortality may be acceptable for some species, implementing fire treatments that can mitigate risk to rare species while still meeting a threshold of ecological objectives (e.g., carrying fire with some thatch or moss consumption) may require targeting a narrow range of burn conditions. Much of the concern regarding risk to and mortality of rare invertebrates during burning is centered on potentially lethal heat 
within the first few centimeters of the soil, as larvae of the endangered Taylor's checkerspot butterfly (Euphydryas editha taylori Edwards) may be in diapause there during the typical prescribed fire season of July to September.

Many studies that examine the effects of fire on insects do so by comparing abundance of species pre-treatment and post-treatment or in burned and unburned areas (Dunwiddie 1991, Black et al. 2013). For example, Schultz and Crone (1998) found significantly higher larval survivorship of Fender's blue butterfly (Icaricia icarioides fenderi Macy) in unburned areas than in burned areas. As many prescribed fire managers appreciate, however, burned and unburned comparisons can be highly variable depending on weather and fuel conditions (New 2014). More generalized assessments of the effects of fire on insects quantify the characteristics and effects of different types of burns in relation to known upper thermal limits of insects and their fire-caused mortality. Much of the research on thermal tolerance has been conducted with agricultural or biological pests (Vermeire et al. 2004, New 2014). For example, egg mortality of grasshoppers is related to oviposition depth and to associated temperatures during simulated burns of varying intensities (Branson and Vermeire 2007). Studies of several native and pest species have concluded that those with an oviposition depth of less than $1 \mathrm{~cm}$ would be susceptible to significant mortality from burning in areas of moderate fuel loads (Branson and Vermeire 2013). Duration of a given temperature is also important when examining thermal tolerance, as a brief exposure of a higher heat may not induce as much mortality as longer exposures to lower temperatures (Rezende et al. 2014). Thus, describing lethality as a function of both temperature and duration - a lethal heat dosage-is useful for assessing overall risk to organisms. Unfortunately, specific temperature-time-mortality models are lacking for many butterfly species that may be at risk from burning, and direct re- search of species-specific lethal heat dosages is made difficult by dramatically declining populations and state and federal listings of some species. However, a recent examination of an upper thermal limit (a temperature at which activity and movement is inhibited) across a wide array of terrestrial insects found an overall mean of $43.0^{\circ} \mathrm{C}$ (Hoffman et al. 2013), providing a general temperature threshold of risk.

Studies of how weather characteristics may affect soil temperatures during burning have mainly contrasted categorical season of burn (i.e., spring versus autumn; Cochrane and Delphey 2002, Vermeire et al. 2004; but see Augustine et al. 2014), while studies on the effects of fuel characteristics have examined both categorical (e.g., gaps versus shrubs) and continuous (e.g., fuel loading) conditions. In grassland, shrubland, and desert fires, lower surface or subsurface soil temperatures have been found in open areas (canopy gaps) than in areas with higher fuel loads (Davis et al. 1989, Brooks 2002, Wright and Clarke 2008). In addition, interruptions of effective fuel continuity from physical trampling (Shea et al. 1996) or high fuel moisture (Knapp and Keeley 2006) can reduce potential for fire spread and lead to patchier burns, potentially increasing organism survival (Paquin and Coderre 1997). The range of weather and fuel moisture conditions in which this patchiness and reduced risk can occur without complete inhibition of fire spread and fuel consumption is likely to be narrow.

We experimentally burned prairie plots under various weather and fuel conditions that typically occur throughout the course of a day during the prescribed fire season in the South Puget Sound, and measured soil temperatures and burn severity. Our objective was to determine the significant predictors of 1) peak subsurface soil temperatures and heat dosages during prescribed fires; and 2) percent cover of unburned or low-severity areas following prescribed fires. Understanding these responses 
increases our understanding of fire behavior and fire effects, and can provide guidance for managers who seek to reduce the overall risk of larval mortality while still meeting ecological objectives when burning in sensitive butterfly habitat.

\section{METHODS}

\section{Study Area}

Our study sites were in prairie remnants in South Puget Sound, Washington. All of our sites were undergoing active restoration, including regular prescribed fires. Historically, these prairies were maintained through several thousand years of anthropogenic burning by Native Americans, and thus have fire-adapted plant communities (Storm and Shebitz 2006). We selected 10 prescribed burn units on eight prairies (Table 1) based on ease of access, feasibility for conducting research burns, similarity of burn history (one to two burns at a $2 \mathrm{yr}$ or $3 \mathrm{yr}$ frequency), and potential for butterfly habitat.

Eight burn units were located on Joint Base Lewis-McChord (JBLM), a military base near Olympia, Washington, USA. Ecological management on JBLM lands is carried out by JBLM personnel in partnership with the Center for Natural Lands Management (CNLM).
A ninth burn unit was located on the Black River-Mima Prairie Glacial Heritage Preserve, owned by Thurston County and managed by CNLM. The tenth burn unit was located at Tenalquot Prairie, owned by The Nature Conservancy and managed by CNLM. Soil type at all prairies is Spanaway gravelly sandy loam, except Glacial Heritage Preserve, which has a Spanaway-Nisqually complex and Sultan silt loam (Natural Resources Conservation Service 2015). Vegetation compositions on all 10 burn units were best described as short-statured bunchgrass prairie in various stages of restoration to native dominance. Dominant species include Roemer's fescue (Festuca idahoensis Elmer subsp. roemeri [Pavlick] S. Aiken), a native grass; small camas (Camassia quamash [Pursh] Greene) and common woolly sunflower (Eriophyllum lanatum [Pursh] Forbes), native forbs; colonial bentgrass (Agrostis capillaris L.), an exotic grass; and narrowleaf plantain (Plantago lanceolata L.) and hairy cat's ear (Hypochaeris radicata L.), both exotic forbs. Invasive shrubs such as Scotch broom (Cytisus scoparius [L.] Link) were largely removed or had limited distribution on most sites.

Prescribed fires in this region are primarily carried out during the summer dry season from July to September, when historical fires are largely believed to have occurred (Storm and

Table 1. Locations and sizes of areas studied; JBLM Training Area 15 and Johnson Prairie each contained two pairs of plots. Abbreviations for each area are in parentheses.

\begin{tabular}{|c|c|c|c|c|}
\hline Name & Latitude & Longitude & $\begin{array}{c}\text { Burn unit extent } \\
\text { (ha) }\end{array}$ & $\begin{array}{c}\text { Time since last burn } \\
\text { (yr) }\end{array}$ \\
\hline JBLM Training Area 6 (TA6) & $47^{\circ} 2^{\prime} 36^{\prime \prime} \mathrm{N}$ & $122^{\circ} 33^{\prime} 54^{\prime \prime} \mathrm{W}$ & 17.0 & 2 \\
\hline JBLM Training Area 15 (TA15) & $47^{\circ} 0^{\prime} 41^{\prime \prime} \mathrm{N}$ & $122^{\circ} 25^{\prime} 59^{\prime \prime} \mathrm{W}$ & 20.0 & 2 \\
\hline JBLM Johnson Prairie (JP) & $46^{\circ} 55^{\prime} 36^{\prime \prime} \mathrm{N}$ & $122^{\circ} 44^{\prime} 5^{\prime \prime} \mathrm{W}$ & 12.0 & 3 \\
\hline JBLM Lower Weir (LW) & $46^{\circ} 55^{\prime} 31^{\prime \prime} \mathrm{N}$ & $122^{\circ} 42^{\prime} 25^{\prime \prime} \mathrm{W}$ & 12.0 & 3 \\
\hline JBLM Upper Weir (UW) & $46^{\circ} 54^{\prime} 57^{\prime \prime} \mathrm{N}$ & $122^{\circ} 41^{\prime} 56^{\prime \prime} \mathrm{W}$ & 22.0 & 3 \\
\hline JBLM South Weir (SW) & $46^{\circ} 54^{\prime} 9^{\prime \prime} \mathrm{N}$ & $122^{\circ} 43^{\prime} 49^{\prime \prime} \mathrm{W}$ & 29.0 & 2 \\
\hline Tenalquot Prairie (TQ) & $46^{\circ} 54^{\prime} 4 " \mathrm{~N}$ & $122^{\circ} 44^{\prime} 16^{\prime \prime} \mathrm{W}$ & 0.4 & 5 \\
\hline Glacial Heritage Preserve (GH) & $46^{\circ} 52^{\prime} 22^{\prime \prime} \mathrm{N}$ & $123^{\circ} 2^{\prime} 17^{\prime \prime} \mathrm{W}$ & 31.0 & 3 \\
\hline
\end{tabular}


Shebitz 2006). Data from the weather station at Chehalis, Washington, indicated that, during this period in 2014 , daytime (0800 hours to 1800 hours) average air temperature ranged from $21^{\circ} \mathrm{C}$ to $25^{\circ} \mathrm{C}$, and average relative humidity (RH) ranged from $43 \%$ to $56 \%$. Precipitation during this three-month period was $99 \mathrm{~mm}$, slightly above the average of $79 \mathrm{~mm}$ for 2004 to 2014 (Western Regional Climate Center 2015).

\section{Experimental Design}

We placed a pair of $26 \mathrm{~m} \times 37 \mathrm{~m}$ plots (Figure 1) within each burn unit, for a total of 20 plots; burn units were already scheduled to be burned as part of the regular prescribed fire program. Plots were placed in pairs simply to capture a wide range of burning conditions: one plot was burned in the early morning when conditions were cool and humid, and the second plot was burned in the afternoon. Plots were at least $20 \mathrm{~m}$ from the nearest road and $10 \mathrm{~m}$ from mowed firebreaks created to serve as control lines during the burns.

Sampling quadrats within each plot were a subset of a larger project (Hill 2015) that used a layout designed for spatial analysis. For this study, each plot contained 14 sampling quadrats arranged along 7 line transects, with two 1 $\mathrm{m} \times 1 \mathrm{~m}$ quadrats spaced $13 \mathrm{~m}$ apart on each

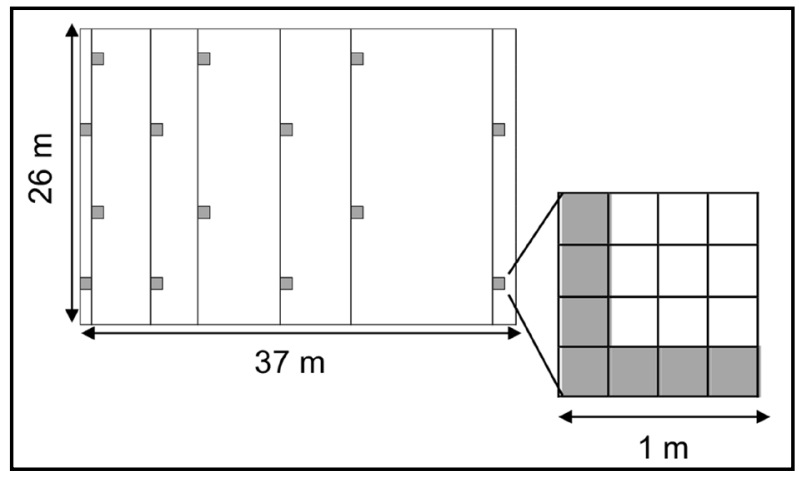

Figure 1. Layout of a plot, showing $1 \mathrm{~m} \times 1 \mathrm{~m}$ sampling quadrats along transects; inset shows the seven $25 \mathrm{~cm} \times 25 \mathrm{~cm}$ sub-quadrats used for assessing cover of open ground and burn severity. transect (Figure 1). Each quadrat was further subdivided into sixteen $25 \mathrm{~cm} \times 25 \mathrm{~cm}$ sub-quadrats; of these, seven were designated for assessing cover of open ground and burn severity.

\section{Pre-Burn Data Collection}

Vegetation structural measurements and fuel moisture assessments were made in each quadrat prior to burning. We visually estimated total standing plant cover $(C)$ in each of the seven $25 \mathrm{~cm} \times 25 \mathrm{~cm}$ sub-quadrats and assessed fuelbed depth by measuring vegetation height $(H)$ in one corner of the quadrat to the nearest $0.1 \mathrm{~m}$. These variables were combined with a standard estimate of bulk density $(B D$; $1.23 \mathrm{~kg} \mathrm{~m}^{-3}$; Burgan and Rothermel 1984) to estimate fuel loading $\left(\mathrm{L} ; \mathrm{kg} \mathrm{m}^{-2}\right)$ in each quadrat as

$$
L=H \times C \times B D .
$$

We also assessed cover of open ground in each sub-quadrat; this cover category represented areas of low fuel continuity that could potentially inhibit fire spread, and included areas of bare ground, sparse litter, rock, moss, and very low-statured $(<2 \mathrm{~cm})$ vegetation, with minimal overhang of neighboring vegetation. Data from the sub-quadrats were averaged to determine the total percentage of open ground in the plot.

Live fuel moisture was estimated within each quadrat through visual assessment of the percent curing and cover of the two main growth forms, grasses and forbs, using a modification of the Guide to Grassland Curing (National Oceanic and Atmospheric Administration 2008) that is based primarily on color and seed head formation. Percent curing of each growth form was then converted to a live fuel moisture percentage using standard fuel modeling tables (Scott and Burgan 2005). Quadrat-level estimates of live fuel moisture were calculated by adding the live fuel moisture of 
each growth form, weighted by their relative abundance.

Dead fuel moisture was measured for each quadrat. To avoid removing actual fuels, we deployed fine fuel moisture sticks consisting of small bundles of straw (12 cm in length, 2.5 $\mathrm{cm}$ diameter) tied at one end with a plastic zip tie, maintaining separation of individual straw pieces at the other end to allow for moisture equilibration; straw pieces were the size of broad-leaved grasses. At least 12 hours prior to burning, we placed a fuel moisture stick just outside of each quadrat and secured it at ground level with a lawn staple. We also recorded thatch depth $(\mathrm{cm})$ at each of these locations. Immediately prior to ignition, we removed each fuel moisture stick and placed it in an airtight bag to prevent moisture loss. Bags were subsequently weighed, opened, dried at $60^{\circ} \mathrm{C}$ for 48 hours, and reweighed. After correcting for the weight of the bag and zip tie, we calculated dead fuel moisture $\left(F M_{\mathrm{d}}\right.$; percent moisture content) as per Pollett and Brown (2007):

$$
F M_{\mathrm{d}}=\frac{100\left(W_{\mathrm{w}}-W_{\mathrm{d}}\right)}{W_{\mathrm{d}}}
$$

where $W_{\mathrm{d}}$ and $W_{\mathrm{w}}$ are the dry and wet weights of the sampled fuel, respectively.

\section{Prescribed Burns}

Prescribed burns were conducted during the main prescribed fire season in this region (Hamman et al. 2011). To ensure data collection over a wide range of weather and fuel conditions, we burned one plot in each burn unit in the morning, when conditions were cooler and more humid, and the other in the afternoon, when conditions were warmer and drier. To control for the potential confounding of time of year on fire behavior, both burns in a burn unit were conducted on the same day. Plots in two burn units were burned four days apart due to logistical constraints, although there was little change in weather conditions or plant phenology during this time.

A consistent ignition pattern was applied in all burns. To mimic the diversity of fire types (head, backing, and flanking) that occur during burns, we applied five point-source ignitions in each plot, one at the center and four halfway between the center and the corners. At each point, we used drip torches to ignite the nearest fuel source, using just enough fuel to light a $50 \mathrm{~cm}$ diameter circle. All points within a plot were ignited within one minute of each other. Mowed firebreaks around the plots were not lit until the nearest plot edge had completely burned, so that the behavior of the experimental plot fire was not influenced by interaction with the blackline fire (a fire to remove fuels around the burn unit to control he burn) ignited for control purposes.

We monitored ambient air temperature $\left({ }^{\circ} \mathrm{C}\right)$, relative humidity $(\mathrm{RH} ; \%)$, and wind speed $\left(\mathrm{m} \mathrm{s}^{-1}\right)$ during each burn using a Kestrel 4000 Weather Meter ${ }^{\mathrm{TM}}$ (Nielsen-Kellerman, Boothwyn, Pennsylvania, USA) positioned 1.3 $\mathrm{m}$ above the ground in a similar fuel type within $20 \mathrm{~m}$ of the plot. Weather was monitored every 30 seconds from ignition until flames had self-extinguished.

We buried an extended-range EL-USB-1$\mathrm{PRO}^{\mathrm{TM}}$ temperature datalogger (Lascar Electronics Ltd., Salisbury, England, United Kingdom) $\sim 1 \mathrm{~cm}$ below the soil surface in the same location as the fuel moisture sticks. Dataloggers recorded the subsurface soil temperature $\left({ }^{\circ} \mathrm{C}\right)$ every second from ignition until flames had self-extinguished. Dataloggers could not be used in two plots due to logistical problems. In three plots, the number of functional dataloggers was reduced from 14 to 11 , due to equipment damage from high heat to three dataloggers in a burn on 15 September 2014.

Subsurface soil temperature data were used to calculate two key responses: the average peak temperature reached during the fire and the amount of lethal heat dosage. For the 
latter, we plotted the duration (minutes; log-transformed) at or above each temperature that was recorded (to $0.1^{\circ} \mathrm{C}$ ) to produce a temperature-time curve for every quadrat. We then compared these curves to a thermal death time (TDT) curve that describes lethality as a function of temperature and duration of heating for insects. Thermal death time curves are lacking for most species, so we used the minimum TDT curve that resulted in 50\% mortality from among the TDT parameters assembled by Rezende et al. (2014) for various life stages of 16 terrestrial insect species from temperate ecosystems. This TDT curve has a slope of $3.9^{\circ} \mathrm{C} \log [\mathrm{min}]^{-1}$ and a $y$-intercept (time $=1$ min) of $41.4{ }^{\circ} \mathrm{C}$, meaning that $50 \%$ mortality would be expected when organisms are subjected to 1 minute at $41.4^{\circ} \mathrm{C}, 10$ minutes at $37.5^{\circ} \mathrm{C}$, or 30 minutes at $35.6^{\circ} \mathrm{C}$. We considered the amount of lethal heat dosage for each quadrat to be the area under the temperature-time curve but above the TDT curve.

Immediately following each fire, we assessed burn severity in the seven sub-quadrats per quadrat. In each sub-quadrat, we visually scored burn severity using a modified version of the National Park Service Fire Effects Monitoring Handbook rating scale for vegetation in grassland fires (USDI National Park Service 2003; Table 2). These data were used to ex- press the potential for insects to survive a fire. Specifically, we calculated the abundance of potential refugia as the percentage of sub-quadrats within a plot that had a burn severity score of 5 (unburned) or 4 (scorched). The scorched severity class consists of very little vegetation consumption (Table 2) and is often associated with an unburned substrate (K.C. Hill, University of Washington, Seattle, USA, personal observation); thus, we included it as potential refugia for insects that may be in the substrate or subsurface during a fire. For analysis, these data were logit transformed (Warton and Hui 2011).

\section{Statistical Analysis}

We used generalized linear models (GLMs) to examine the relationships of three response variables to fuel and weather conditions during the prescribed burns. Response variables were 1) peak soil temperature during the burn; 2) probability and amount of lethal heat dosage; and 3) abundance of potential refugia. Potential predictor variables included air temperature $\left({ }^{\circ} \mathrm{C}\right), \mathrm{RH}(\%)$, wind speed (m $\left.\mathrm{s}^{-1}\right)$, live fuel moisture $(\%)$, dead fuel moisture $(\%)$, fuel loading $\left(\mathrm{kg} \mathrm{m}^{-2}\right)$, thatch depth $(\mathrm{cm})$, cover of open ground (\%), and the Julian calendar day of burning. We conducted all analy-

Table 2. Vegetation fire-severity class descriptions, modified from National Park Service Fire Effects Monitoring Handbook (USDI National Park Service 2003).

\begin{tabular}{ll}
\hline Category & \multicolumn{1}{c}{ Visual description } \\
\hline $5=$ Unburned & Not burned \\
\hline = Scorched & $\begin{array}{l}\text { Foliage scorched } \\
\text { Grasses with approximately two inches of stubble; foliage and smaller twigs of } \\
\text { associated species partially to completely consumed; some plant parts may still } \\
\text { be standing; bases of plants are not deeply burned and are still recognizable }\end{array}$ \\
$\begin{array}{l}\text { Unburned grass stubble usually less than two inches tall, and mostly confined } \\
\text { to an outer ring; for other species, foliage completely consumed, plant bases are } \\
\text { burned to ground level and obscured in ash immediately after burning; burns } \\
\text { tend to be uniform }\end{array}$ \\
$\begin{array}{l}\text { No unburned grasses above the root crown; for other species, all plant parts } \\
\text { consumed leaving some or no major stems or trunks, any left are deeply charred; } \\
\text { this severity class is uncommon due to the short burnout time of grasses }\end{array}$ \\
\hline
\end{tabular}


ses at the plot scale, averaging across quadrats for fuel measurements. Air temperature, $\mathrm{RH}$, and wind speed were averaged over the time period of each burn. We did not include the categorical variable of morning versus afternoon burn as a predictor variable, as individual weather conditions varied within these categories and were more informative for refining potential burn prescriptions to meet soil temperature and severity objectives. We did not include burn unit as a random effect in our models, as soils and vegetation stature were similar at all sites; the range of fuel characteristics such as loading and thatch depth represented across our sites was minimal due to similar management and burn histories at all sites.

We analyzed peak soil temperature and abundance of potential refugia with linear models using normal error terms. We analyzed lethal heat dosage with a two-part hurdle model (Zuur et al. 2009). First, we used a GLM with binomial errors to predict the binary response of whether any lethal heat dosage occurred in a plot. Second, for those plots in which lethal heat dosage occurred, we used a GLM with gamma errors and a log link to analyze the amount of lethal heat dosage (averaged across all quadrats in a plot).

We screened data for potential outliers and predictors for skewed distributions and multicollinearity. Air temperature and $\mathrm{RH}$ were strongly negatively correlated $(r=-0.89)$, so we restricted our attention to models that did not include both. We used model selection to identify optimal models on the basis of Akaike Information Criterion corrected for small sample size $\left(\mathrm{AIC}_{c}\right)$. Specifically, we identified a set of candidate models as those with $\mathrm{AIC}_{c}$ within two units of the model with the smallest $\mathrm{AIC}_{c}$, and then chose as our final model the most parsimonious model that maintained explanation of variance and included significant $(P<0.05)$ predictors. We evaluated final models for constancy of variance, distribution of errors, and patterns in residuals. We also test- ed whether there was evidence of interactions between main terms.

We conducted all analyses in $R$ version 3.1.2 (R Foundation for Statistical Computing, Vienna, Austria), using the following packages: stats version 3.1.2, car version 2.0-24, mgcv version 1.8-3, MuMin version 1.13.4, flux version 0.3-0, ggplot2 version 1.0.1, and grid version 3.1.2.

\section{RESULTS}

Prescribed burns were conducted between 22 July 2014 and 22 September 2014; the earliest burn was lit at 0804 hours and the latest burn was lit at 1716 hours. Burn durations ranged from 9 minutes to 53 minutes (Table 3, Table 4). During the burns, average air temperatures ranged from $14^{\circ} \mathrm{C}$ to $32^{\circ} \mathrm{C}, \mathrm{RH}$ ranged from $32 \%$ to $88 \%$, and wind speed ranged from $0.5 \mathrm{~m} \mathrm{~s}^{-1}$ to $3.7 \mathrm{~m} \mathrm{~s}^{-1}$. Dead fuel moistures ranged from $2.3 \%$ to $30.0 \%$ and fuel load ranged from $0.18 \mathrm{~kg} \mathrm{~m}^{-2}$ to 0.65 $\mathrm{kg} \mathrm{m}^{-2}$.

Average peak soil temperature was strongly positively related to air temperature and negatively related to dead fuel moisture $\left(\mathrm{R}^{2}\right.$ adj $=0.829, P \leq 0.001)$. Scatterplots show sharp thresholds in soil temperature when burning at air temperatures above $\sim 26^{\circ} \mathrm{C}$ and dead fuel moistures below $\sim 7 \%$ (Figure 2). Soil temperatures were also more variable within plots when dead fuel moistures were lower and air temperatures were higher (Figure 2).

Ten of the eighteen plots with temperature measurements experienced a lethal heat dosage (a temperature-time curve that crossed the TDT curve) in at least one quadrat, with the afternoon-burned plots holding the majority of these occurrences (Figure 3). When this happened, the amount of lethal heat dosage, as measured by the area between the temperature-time curve and the TDT curve, ranged from $0.1{ }^{\circ} \mathrm{C} * \log [\mathrm{min}]$ to $35.7^{\circ} \mathrm{C} * \log [\mathrm{min}]$. Dead fuel moisture at the time of burning was the best predictor of the probability of a lethal 
Table 3. Average weather and fuel conditions for prescribed burns conducted in South Puget Sound, Washington, USA, prairies. All codes for the site listings are detailed in Table 1.

\begin{tabular}{|c|c|c|c|c|c|c|c|c|c|c|c|}
\hline \multirow{2}{*}{$\begin{array}{l}2014 \\
\text { burn } \\
\text { date }\end{array}$} & \multirow[b]{2}{*}{ Site } & \multirow{2}{*}{$\begin{array}{l}\text { Time of } \\
\text { ignition } \\
\text { (hours) }\end{array}$} & \multirow{2}{*}{$\begin{array}{c}\text { Burn } \\
\text { length } \\
\text { (min) }\end{array}$} & \multirow[b]{2}{*}{$\begin{array}{l}\text { Air temp. } \\
\quad\left({ }^{\circ} \mathbf{C}\right)\end{array}$} & \multirow[b]{2}{*}{$\begin{array}{l}\text { RH } \\
(\%)\end{array}$} & \multirow{2}{*}{$\begin{array}{l}\text { Wind } \\
\text { speed } \\
\left(\mathrm{m} \mathrm{s}^{-1}\right)\end{array}$} & \multicolumn{2}{|c|}{ Fuel moisture } & \multirow{2}{*}{$\begin{array}{c}\text { Fuel } \\
\text { loading } \\
\left(\mathrm{kg} \mathrm{m}^{-2}\right)\end{array}$} & \multirow{2}{*}{$\begin{array}{l}\text { Thatch } \\
\text { depth } \\
\text { (cm) }\end{array}$} & \multirow{2}{*}{$\begin{array}{c}\text { Open } \\
\text { ground } \\
\text { cover }(\%)\end{array}$} \\
\hline & & & & & & & $\begin{array}{l}\text { Live } \\
(\%)\end{array}$ & $\begin{array}{c}\text { Dead } \\
(\%)\end{array}$ & & & \\
\hline $22 \mathrm{Jul}$ & LW & 0942 & 33 & 15.9 & 71.2 & 0.5 & 74.7 & 14.5 & 0.52 & 2.4 & 0.6 \\
\hline $22 \mathrm{Jul}$ & LW & 1341 & 11 & 18.9 & 64.5 & 1.2 & 81.3 & 8.0 & 0.59 & 2.8 & 0.4 \\
\hline 5 Aug & TA6 & 0908 & 35 & 16.4 & 77.8 & 1.5 & 60.8 & 11.9 & 0.46 & 1.7 & 2.0 \\
\hline 5 Aug & TA6 & 1430 & 9 & 28.9 & 46.6 & 1.7 & 61.2 & 3.4 & 0.55 & 1.9 & 0.2 \\
\hline 7 Aug & $\mathrm{JP}$ & 0804 & 27 & 14.4 & 87.9 & 1.9 & 58.8 & 13.3 & 0.56 & 2.2 & 0.7 \\
\hline 7 Aug & JP & 0920 & 20 & 15.2 & 84.3 & 2.1 & 66.4 & 12.3 & 0.63 & 3.3 & 0.8 \\
\hline 7 Aug & JP & 1400 & 20 & 26.5 & 46.3 & 1.7 & 53.6 & 2.7 & 0.56 & 1.7 & 1.6 \\
\hline 7 Aug & JP & 1501 & 9 & 28.1 & 41.6 & 2.0 & 63.4 & 2.3 & 0.54 & 2.4 & 0.5 \\
\hline $15 \mathrm{Aug}$ & UW & 1238 & 28 & 23.8 & 67.0 & 1.2 & 59.4 & 30.0 & 0.49 & 2.3 & 1.5 \\
\hline $18 \mathrm{Aug}$ & TA15 & 0858 & 32 & 24.0 & 69.4 & 0.5 & 66.1 & 26.5 & 0.51 & 1.5 & 3.3 \\
\hline $18 \mathrm{Aug}$ & TA15 & 1002 & 20 & 25.9 & 59.7 & 0.9 & 59.8 & 21.4 & 0.53 & 1.6 & 2.3 \\
\hline 18 Aug & TA15 & 1534 & 37 & 31.4 & 40.5 & 1.5 & 60.9 & 5.8 & 0.50 & 2.0 & 3.5 \\
\hline 18 Aug & TA15 & 1716 & 20 & 32.0 & 44.6 & 0.9 & 60.4 & 5.8 & 0.53 & 1.8 & 1.4 \\
\hline 19 Aug & UW & 1632 & 15 & 26.4 & 50.7 & 3.7 & 64.4 & 4.3 & 0.44 & 2.1 & 1.7 \\
\hline $25 \mathrm{Aug}$ & SW & 0900 & 28 & 21.1 & 70.4 & 0.6 & 58.4 & 16.3 & 0.65 & 2.7 & 1.6 \\
\hline $25 \mathrm{Aug}$ & SW & 1505 & 13 & 29.0 & 35.5 & 2.2 & 60.3 & 3.1 & 0.55 & 1.8 & 5.0 \\
\hline $15 \mathrm{Sep}$ & GH & 1014 & 20 & 20.2 & 53.3 & 1.5 & 71.1 & 8.2 & 0.18 & 2.7 & 15.0 \\
\hline $15 \mathrm{Sep}$ & GH & 1230 & 12 & 28.1 & 32.3 & 2.3 & 61.9 & 4.4 & 0.25 & 2.5 & 13.4 \\
\hline $18 \mathrm{Sep}$ & TQ & 1331 & 53 & 19.7 & 72.6 & 2.0 & 58.6 & 30.0 & 0.48 & 2.8 & 2.7 \\
\hline \multirow[t]{4}{*}{$22 \mathrm{Sep}$} & TQ & 1600 & 17 & 22.8 & 53.3 & 0.9 & 51.1 & 13.1 & 0.52 & 3.5 & 2.5 \\
\hline & \multicolumn{2}{|c|}{ Minimum } & 9 & 14.4 & 32.3 & 0.5 & 51.1 & 2.3 & 0.18 & 1.5 & 0.2 \\
\hline & \multicolumn{2}{|r|}{ Mean } & 23 & 23.4 & 58.5 & 1.5 & 62.6 & 11.9 & 0.50 & 2.3 & 3.0 \\
\hline & \multicolumn{2}{|c|}{ Maximum } & 37 & 32.0 & 87.9 & 3.7 & 81.3 & 30.0 & 0.65 & 3.5 & 15.0 \\
\hline
\end{tabular}

heat dosage occurring in a plot $(P=0.044$; Figure 4a). For plots in which this lethal threshold was exceeded, the ambient air temperature during burning was the most influential factor on the average amount of lethal heat dosage ( $P \leq 0.001$; Figure $4 b)$.

The abundance of potential refugia was positively related to dead fuel moisture, preburn cover of open ground, and the interaction between these two predictors $\left(\mathrm{R}^{2}{ }_{\text {adj }}=0.779, P\right.$ $\leq 0.001$; Figure 5).

\section{DISCUSSION}

\section{Soil Temperatures}

Peak subsurface soil temperatures during burning were strongly bimodal (reflecting morning versus afternoon burns), with separation at a soil temperature of $\sim 38^{\circ} \mathrm{C}$ (Figure 2), and were clearly related to both air temperature and dead fuel moisture. These relationships show that variation in time of burn within a day can produce as much variation in soil temperatures as can occur when burning in dif- 
Table 4. Average soil temperatures, heat dosage, and severity for prescribed burns conducted in South Puget Sound, Washington, USA, prairies. All codes for the site listings are detailed in Table 1.

\begin{tabular}{|c|c|c|c|c|c|c|c|}
\hline $\begin{array}{c}2014 \\
\text { burn date }\end{array}$ & Site & $\begin{array}{l}\text { Time of } \\
\text { ignition } \\
\text { (hours) }\end{array}$ & $\begin{array}{c}\text { Burn length } \\
\text { (min) }\end{array}$ & $\begin{array}{c}\text { Peak soil } \\
\text { temp. }\left({ }^{\circ} \mathbf{C}\right)\end{array}$ & $\begin{array}{c}\text { Lethal heat dose }^{\text {a }} \\
\left({ }^{\circ} \mathrm{C} * \log [\mathrm{min}]\right)\end{array}$ & $\begin{array}{c}\text { Quadrats } \\
\text { with lethal } \\
\text { heat dose }(n)\end{array}$ & $\begin{array}{c}\text { Unburned or } \\
\text { scorched area } \\
\text { cover }(\%)\end{array}$ \\
\hline $22 \mathrm{Jul}$ & LW & 0942 & 33 & 22.7 & 0.00 & 0 & 25.5 \\
\hline $22 \mathrm{Jul}$ & LW & 1341 & 11 & 27.4 & 0.00 & 0 & 5.1 \\
\hline 5 Aug & TA6 & 0908 & 35 & 28.3 & 0.17 & 1 & 18.4 \\
\hline 5 Aug & TA6 & 1430 & 9 & 54.8 & 9.42 & 14 & 0.0 \\
\hline 7 Aug & JP & 0804 & 27 & 25.1 & 0.00 & 0 & 4.1 \\
\hline 7 Aug & JP & 0920 & 20 & 29.3 & 0.20 & 1 & 0.0 \\
\hline 7 Aug & JP & 1400 & 20 & 47.3 & 6.96 & 11 & 0.0 \\
\hline 7 Aug & JP & 1501 & 9 & 41.2 & 1.59 & 8 & 0.0 \\
\hline 15 Aug & UW & 1238 & 28 & 27.6 & 0.00 & 0 & 25.5 \\
\hline 18 Aug & TA15 & 0858 & 32 & 22.1 & 0.00 & 0 & 94.9 \\
\hline 18 Aug & TA15 & 1002 & 20 & 26.9 & 0.00 & 0 & 43.9 \\
\hline 18 Aug & TA15 & 1534 & 37 & 47.2 & 10.45 & 11 & 16.3 \\
\hline 18 Aug & TA15 & 1716 & 20 & & & & 5.1 \\
\hline 19 Aug & UW & 1632 & 15 & 40.4 & 1.74 & 8 & 13.3 \\
\hline 25 Aug & SW & 0900 & 28 & 24.4 & 0.00 & 0 & 18.4 \\
\hline 25 Aug & SW & 1505 & 13 & 41.9 & 2.73 & 9 & 15.3 \\
\hline $15 \mathrm{Sep}$ & $\mathrm{GH}$ & 1014 & 20 & 34.5 & 1.24 & 2 & 42.9 \\
\hline $15 \mathrm{Sep}$ & GH & 1230 & 12 & 45.2 & 3.09 & 6 & 6.1 \\
\hline $18 \mathrm{Sep}$ & TQ & 1331 & 53 & 23.4 & 0.00 & 0 & 92.9 \\
\hline \multirow[t]{4}{*}{$22 \mathrm{Sep}$} & TQ & 1600 & 17 & & & & 17.4 \\
\hline & & Minimum & 9 & 22.1 & 0.00 & 0 & 0.0 \\
\hline & & Mean & 23 & 33.9 & 2.09 & 4 & 22.3 \\
\hline & & Maximum & 37 & 54.8 & 10.45 & 14 & 94.9 \\
\hline
\end{tabular}

${ }^{a}$ Lethal heat dosage calculated as the area under the temperature-time curve but above the TDT curve

ferent seasons (Brooks 2002, Wright and Clarke 2008, Strong et al. 2013). As all of our burns occurred when vegetation was in a similar phenological stage, future exploration of how time of day and season of burn interact to affect soil temperatures is warranted.

Our results indicated that burning when dead fuel moisture was $>7 \%$ was unlikely to result in soil temperatures that could be considered substantially lethal for insect larvae. However, it is important to note that our fine dead fuel moisture values were directly mea- sured in the field using fuel sticks; whereas, in practice, fire managers often rely on published tables to estimate fuel moisture based on weather conditions, time of day, and time of year (National Wildfire Coordinating Group 2014). Our measured values were only moderately correlated $(r=0.5)$ with estimates from these tables (Figure 6)-likely due to generalizations in the tables that may not account for regional differences. In either method, when fuel moisture was somewhat dry (i.e., less than $10 \%$ ), the field-measured fuel moistures were 


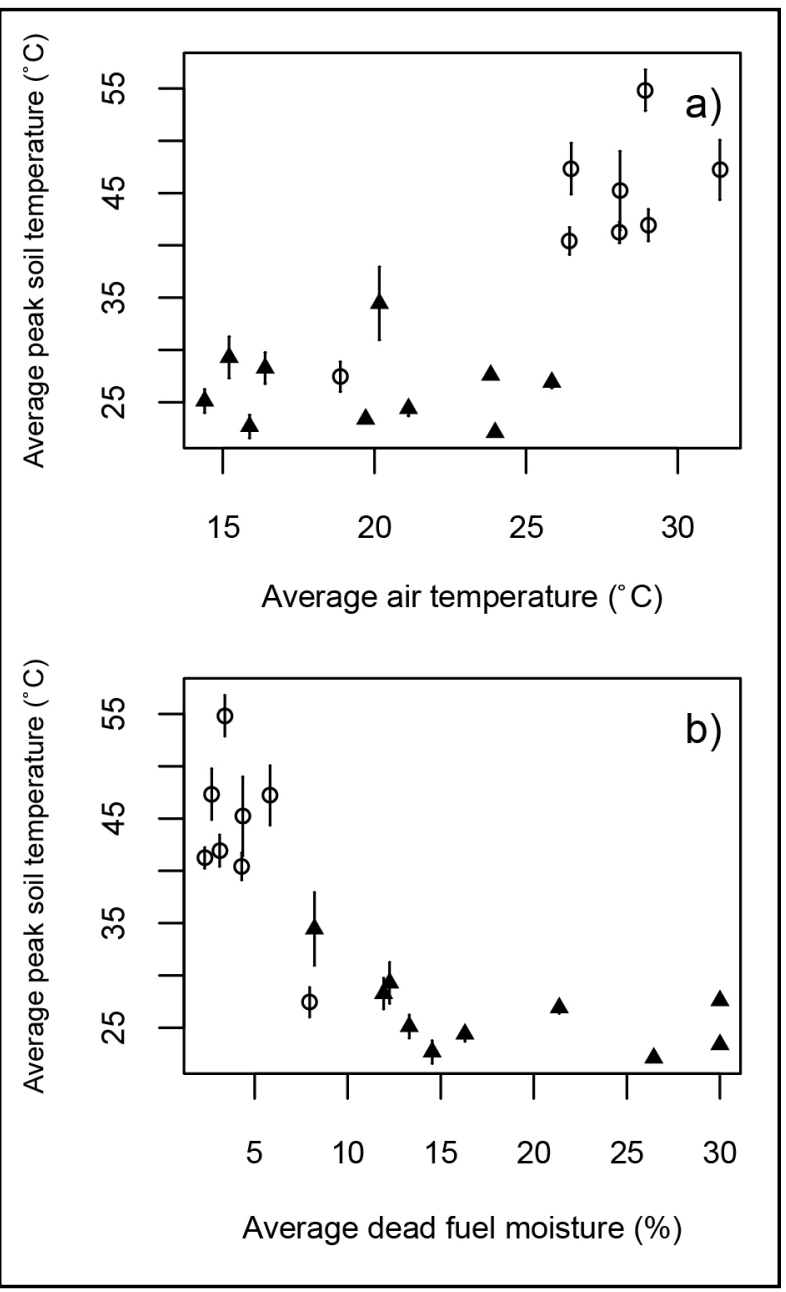

Figure 2. Raw data for relationships of average peak soil temperature at $1 \mathrm{~cm}$ depth with a) average air temperature, and $b$ ) average dead fuel moisture at the time of the burn. Error bars represent standard error of the mean based on variation among quadrats within each plot. Morning burns are filled triangles $(\boldsymbol{\Lambda})$ and afternoon burns are open circles (O).

$1 \%$ to $5 \%$ below those estimated from tables (Figure 6). Therefore, we suggest adding 1\% to $5 \%$ to our results when considering fine dead fuel moisture prescriptions for these types of sensitive habitats.

In contrast to studies of burning in shrublands and deserts (Davis et al. 1989, Brooks 2002, Wright and Clarke 2008), neither thatch depth nor fuel loading had a significant relationship with soil temperatures in our sites. This may reflect differences in methods of measurement (thermal paints and temperature dataloggers may have dissimilar response times to heating) or differences in vegetation. Grasslands have more uniform and continuous vegetation cover than shrublands, which are characterized by distinct canopy gaps separating large shrubs, and thus have higher variation in fuel loading. The importance of vegetation structure is supported by the much smaller range of peak surface temperatures observed in grasslands than in shrublands (Neary et al. 1999). In addition, the plots in our study were established in potential butterfly habitat mostly free of large invasive shrubs and heavy fuel loads that can dramatically increase soil temperatures and heat dosages. A recent study that modeled peak soil temperatures during semi-arid grassland fires in relation to fuel and weather conditions found fuel load to be a much stronger predictor than weather conditions (Augustine et al. 2014), but it evaluated a much larger range of fuel loads and narrower range of weather conditions than occurred on our sites and during our burns. Thus, the potential effect of a wider range of fuel loads on soil temperatures in our system may not be adequately captured here.

In our study, average peak soil temperatures were more variable when dead fuel moistures were lower (Figure 2). This likely reflects microsite variation that is amplified during drier and hotter burns; rocks or patches of dry organic matter may elevate local temperatures while other locations remain cooler. When fuels have more moisture, these differences are muted, resulting in a more uniform distribution of temperatures.

\section{Lethal Heat Dosages}

Different variables predicted whether a lethal heat dosage occurred and the magnitude of that dosage. Dead fuel moisture was the best predictor of whether a lethal heat dosage occurred (Figure 4a). All but two of the ten plots in which this occurred had dead fuel moistures of $8 \%$ or less; the two plots that ex- 


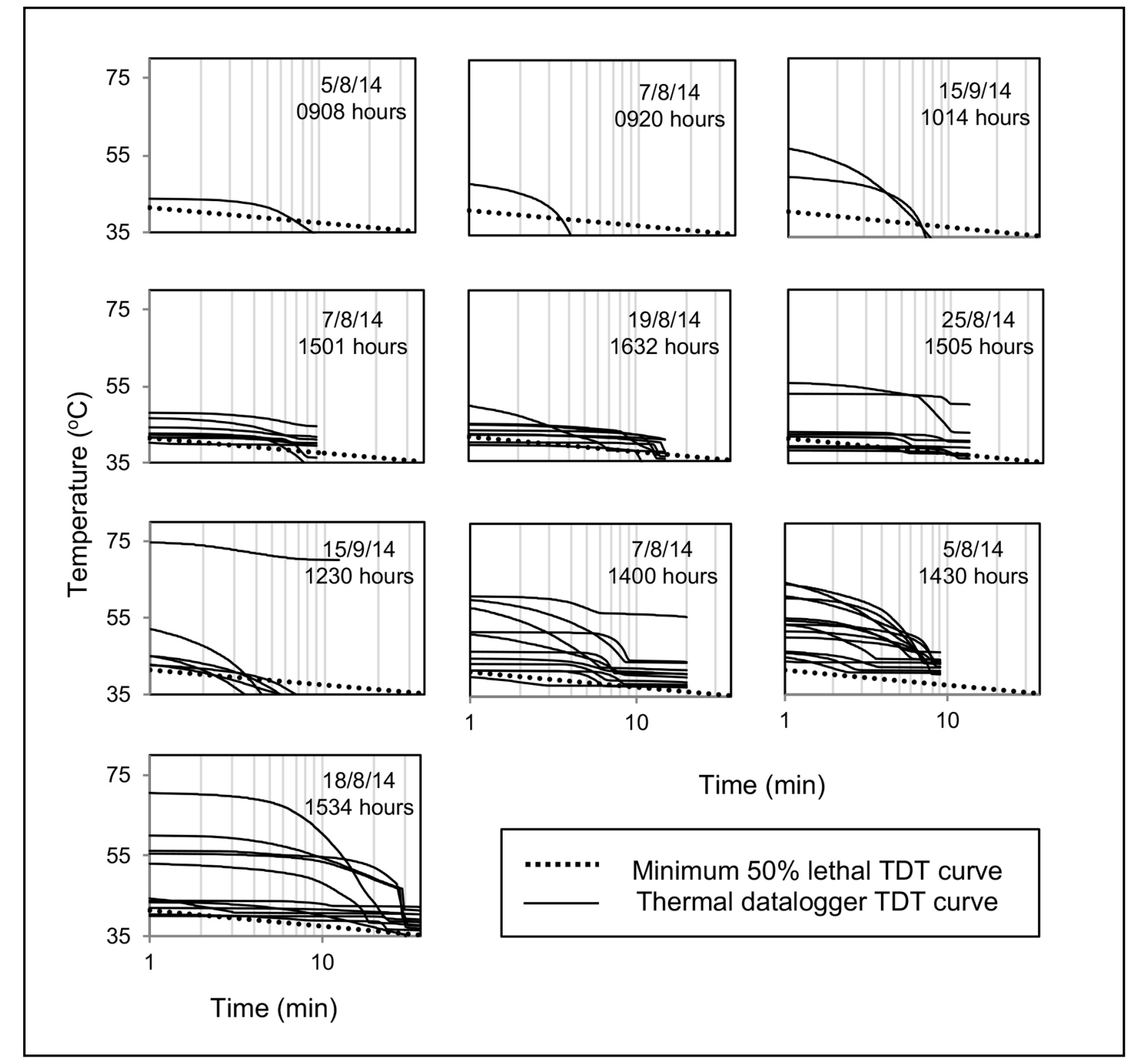

Figure 3. Temperature-time duration curves from thermal dataloggers (solid lines) in our study in comparison to the minimum 50\% lethal thermal death time (TDT) curve (dotted line) from experimental data gathered by Rezende et al. (2014), graphed for the 10 plots in which a lethal heat dosage occurred. Each datalogger curve represents one quadrat in the plot, and only quadrats in which a lethal heat dosage occurred are shown. $X$-axes are logarithmic time $(\min )$ and $y$-axes are temperature $\left({ }^{\circ} \mathrm{C}\right)$, with datalogger curves showing the time spent at or above each temperature. Plots are shown in order of increasing mean lethal heat dosage. Burn date and burn time are indicated in corner of each graph; additional details for each burn are in Table 3 and Table 4.

perienced a lethal heat dosage at a higher dead fuel moisture (11\% to $12 \%)$ recorded minimal $\left(<1.0^{\circ} \mathrm{C} * \log [\mathrm{min}]\right)$ average heat dosages (see first two graphs in Figure 3). The magnitude of lethal heat dosages was best predicted by ambient air temperature (Figure 4b), with the highest average heat dosages occurring when air temperature was $>26^{\circ} \mathrm{C}$, providing further guidance for burn management decisions in sensitive habitat in this system. 


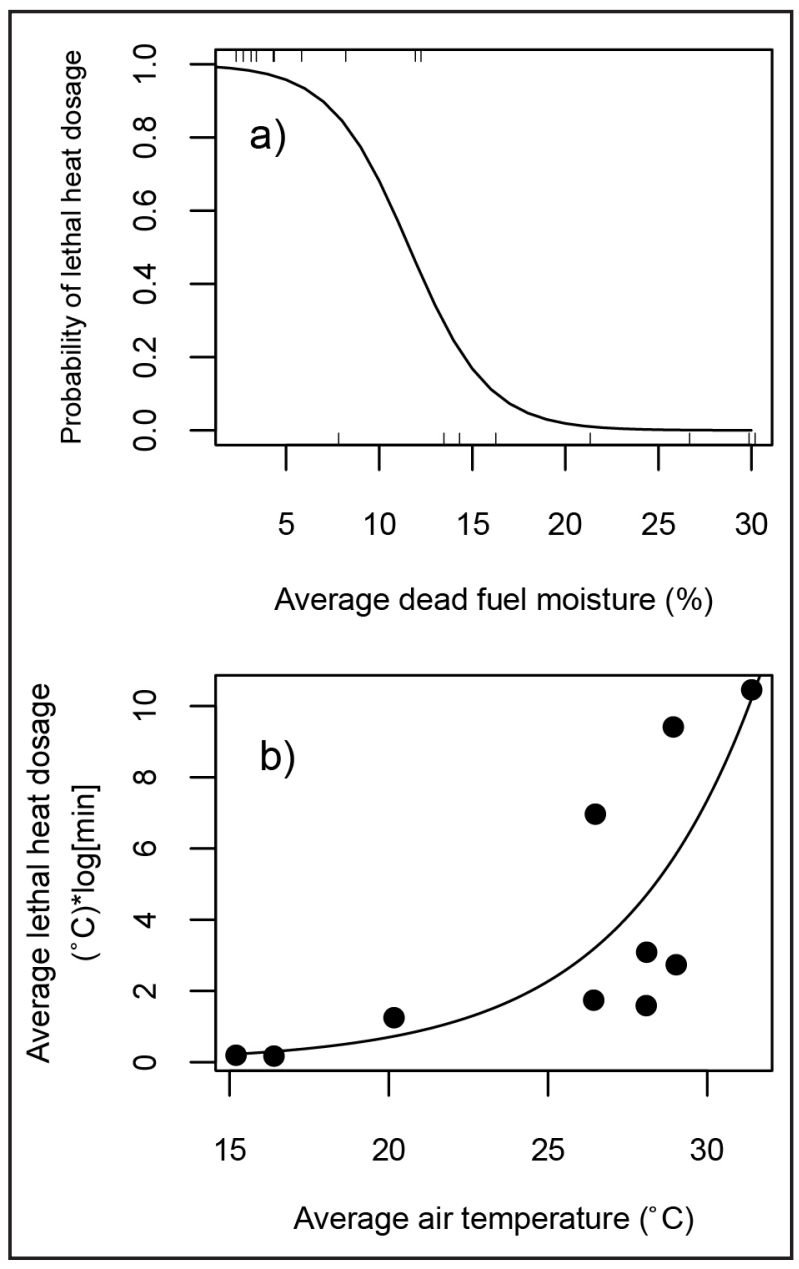

Figure 4. a) Probability of a lethal heat dosage as a function of average dead fuel moisture at the time of the burn, as predicted using logistic regression; checks along the top and bottom axes show actual occurrence of a lethal heat dosage as a function of dead fuel moisture. b) Average amount of lethal heat dosage as a function of average air temperature at the time of the burn, for those plots in which a lethal heat dosage occurred (averages include quadrats with zero lethal heat dosage). Solid line represents the predicted values from a generalized linear model with a gamma error distribution using a log link.

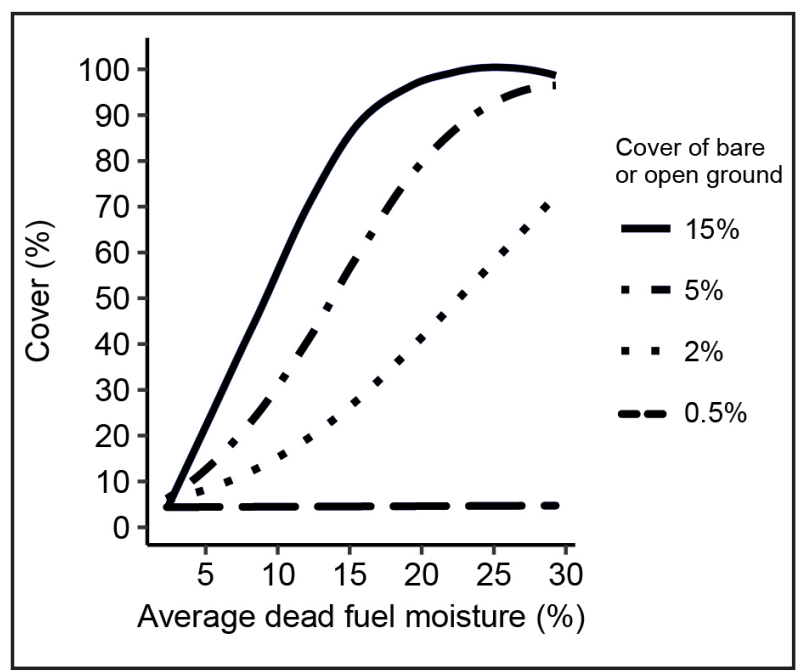

Figure 5. Interaction plot showing predicted cover of potential refugia (unburned or scorched areas after burning) as a function of the average dead fuel moisture and representative amounts of preburn open ground.

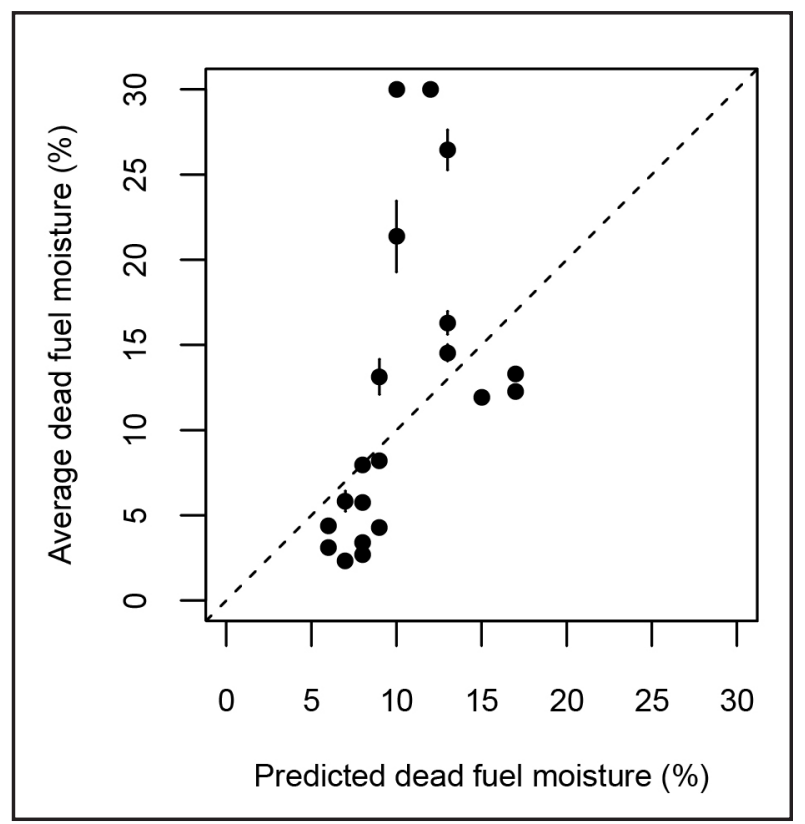

Figure 6. Observed dead fuel moisture (plot average from fine fuel sticks) as a function of predicted dead fuel moisture from standard fuel modeling tables (National Wildfire Coordinating Group 2014) using weather, slope, and time of year. Error bars represent standard error of the mean. Dashed diagonal line indicates a 1:1 line. 
The thermal death time curve that we chose provides a conservative assessment of insect lethality in lieu of having thermal tolerance data for the species in our system. This provides a general basis for examination of potential insect mortality; future work should determine species-specific curves for species of interest.

\section{Burn Severity}

The idea behind burning in moist conditions to generate a patchier burn is that the increased fuel moisture effectively reduces fuel continuity and can increase patches of unburned areas that serve as insect refugia. Fuel continuity is a function of vegetation structure, including the horizontal and vertical spacing between patches of vegetation; in the absence of these spaces, increasing fuel moisture can effectively reduce continuity (Miller and Urban 2000) and increase burn patchiness (Knapp and Keeley 2006). This idea was not strongly supported by our results, as the optimal model for explaining the abundance of potential refugia included an interaction between dead fuel moisture and pre-burn cover of open ground. Higher dead fuel moistures only increased post-burn cover of unburned areas when the pre-burn fuel structure included higher cover of open ground (Figure 5). Without this pre-existing open ground, high fuel moistures did not reduce continuity enough to leave unburned or low-consumption areas.

In a typical prescribed fire in sensitive butterfly habitat in South Puget Sound prairies, a patchy burn with some unburned areas is preferable to more homogeneous consumption of fuel (Figure 7); leaving approximately $20 \%$ to $25 \%$ cover of unburned or low-severity areas would be a common objective (C. Fimbel, Center for Natural Lands Management, Olympia, Washington, USA, personal communication). When burning in areas with at least a small amount of open ground (i.e., $\geq 2 \%$ ), somewhat higher dead fuel moistures $(8 \%$ to

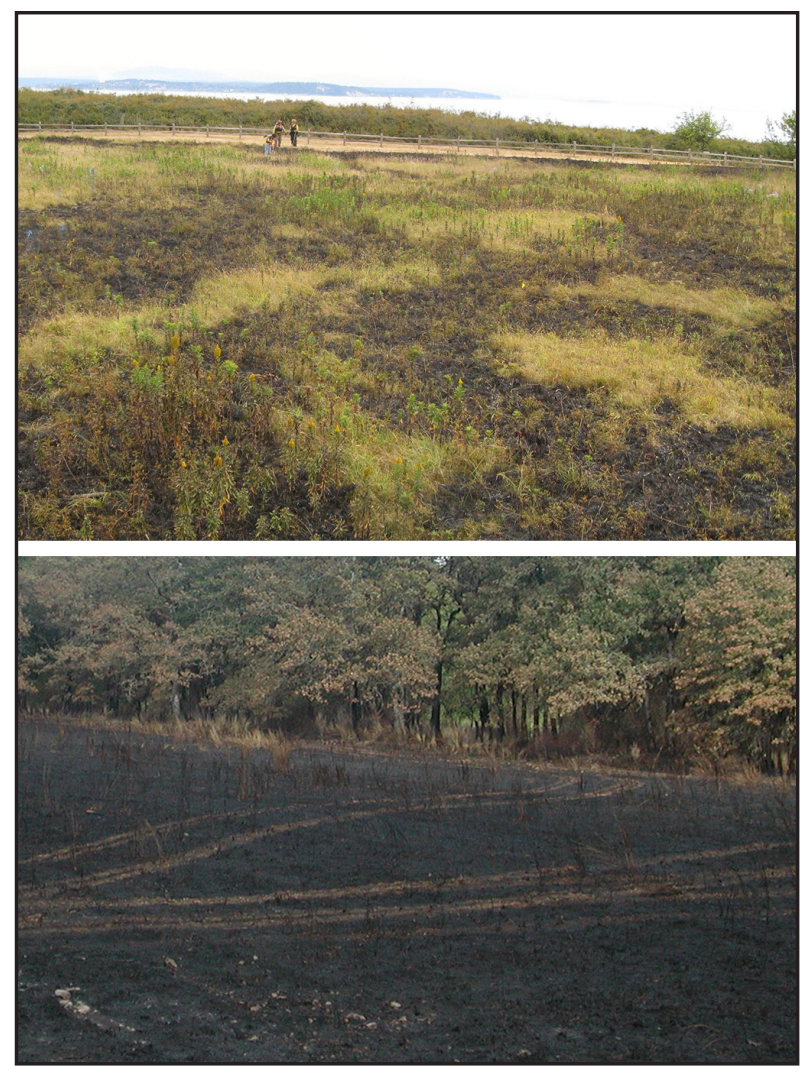

Figure 7. Example photos of a patchy burn with unburned refugia areas (top) and a homogenous and more severe burn (bottom) in Puget Sound prairies.

$15 \%$ ) can help increase the cover of unburned or low-severity areas toward the target range (Figure 5). These results illustrate the complex interplay between high fuel moisture and physical gaps in fuel, and how each can reduce the effective fuel continuity and fire spread.

\section{Management Implications}

Burning in ways that minimize mortality of sensitive species is a key objective of land managers in Pacific Northwest prairies, not only for butterflies, but also for rare plants (Dunwiddie et al. 2001) and lichen communities (Calabria et al. 2016). This study shows that target conditions for burning in potentially sensitive butterfly habitat in this region should have an air temperature of less than $26^{\circ} \mathrm{C}$ and 
fine dead fuel moisture from published tables (National Wildfire Coordinating Group 2014) of at least $9 \%$. Given the average burn-day conditions for the prescribed fire program in South Puget Sound prairies- $22{ }^{\circ} \mathrm{C}, 52 \% \mathrm{RH}$, $8 \%$ fine dead fuel moisture (K.C. Hill, unpublished data) - these target conditions are reasonable and achievable during summer burning in this region mainly by focusing on conducting fires earlier in the morning when these cooler and more moist conditions can be present. However, meeting other specific burn objectives in butterfly habitat, such as moss and thatch reduction or creation of a certain percentage of bare ground, may or may not be possible in these conditions. Future work is needed to map out the balance and overlap of these two goals. The variation in fire effects we observed when burning as weather conditions change over the course of a day can also be harnessed as a way to enhance overall burn heterogeneity across a landscape, creating a mosaic effect.

Soil moisture was not measured in this study, but can be an important factor. Moist soil can lower the absolute peak burn temperatures that occur at and below the surface (Wright and Clarke 2008), but can also increase the depth to which a given peak temperature penetrates through increased thermal conductivity (DeBano et al. 1998). In addition, lethal temperature thresholds for both plant roots and soil organisms can be lower in moist soils due to these effects of soil water on the transfer and storage of heat energy (DeBa- no et al. 1998). This would potentially affect the lethal thresholds given by the TDT curves gathered by Rezende et al. (2014; Figure 3), highlighting the dynamic nature of lethal temperatures and the need for larval mortality studies for the butterflies in this region.

\section{Conclusions}

The results of this study suggest that targeting specific weather and fuel conditions during prescribed burns in sensitive butterfly habitat of South Puget Sound prairies can decrease peak soil temperatures and lethal heat dosages and increase the abundance of unburned or low-severity areas. Therefore, by more narrowly constraining the conditions under which prescribed fires are conducted, mortality risk for soil-dwelling organisms can be mitigated. The most important determinants of these burn outcomes were ambient air temperature and dead fuel moisture, with fuel structure (cover of open ground) also affecting fuel continuity and therefore burn severity patterns. The recommended thresholds for conducting risk-reduced burns are within the normal range of weather patterns used for prescribed fires in the Sound Puget Sound burn program and highlight the potential advantages of morning burns, but a closer examination of balancing specific burn objectives with risk reduction is warranted. Finally, future research to refine strategies for reducing risk to soil-dwelling larvae in these habitats should evaluate larval responses to prescribed burns.

\section{ACKNOWLEDGEMENTS}

We thank M. McKinley, Center for Natural Lands Management, and J. Richardson, Joint Base Lewis-McChord Fish and Wildlife Department, for providing study area access and prescribed burn crews and resources. We thank S. Hamman, Center for Natural Lands Management, and C. Halpern, University of Washington, for helpful comments on an earlier draft. This research was funded by a National Science Foundation Graduate Research Fellowship under grant number DGE-1256082. 


\section{LITERATURE CITED}

Augustine, D.J., J.D. Derner, and D.P. Smith. 2014. Characteristics of burns conducted under modified prescriptions to mitigate limited fuels in a semi-arid grassland. Fire Ecology 10(2): 36-47. doi: 10.4996/fireecology.1002036

Black, S.H., C. Fallon, R. Hatfield, and C. Mazzacano. 2013. Controlled burning and Mardon skipper: summary of Mardon skipper Coon Mountain burn site occupancy study 2009-2013. Final report to US Forest Service, Oregon Zoo, and US Fish and Wildlife Service. Xerces Society, Portland, Oregon, USA.

Bradstock, R.A., M. Bedward, A.M. Gill, and J.S. Cohn. 2005. Which mosaic? A landscape ecological approach to evaluating interactions between fire regimes, habitats and animals. Wildlife Research 32: 409-423. doi: 10.1071/WR02114

Branson, D.H., and L.T. Vermeire. 2007. Grasshopper egg mortality mediated by oviposition tactics and fire intensity. Ecological Entomology 32: 128-134. doi: 10.1111/j. 1365-2311.2006.00847.x

Branson, D.H., and L.T. Vermeire. 2013. Heat dosage and oviposition depth influence egg mortality of two common rangeland grasshopper species. Rangeland Ecology and Management 66: 110-113. doi: 10.2111/REM-D-11-00187.1

Brooks, M.L. 2002. Peak fire temperatures and effects on annual plants in the Mojave Desert. Ecological Applications 12: 1088-1102. doi: 10.1890/1051-0761(2002)012[1088:PFTAEO] 2.0.CO;2

Burgan, R.E., and R.C. Rothermel. 1984. BEHAVE: fire behavior prediction and fuel modeling system-FUEL subsystem. USDA Forest Service General Technical Report INT-167, Intermountain Forest and Range Experiment Station, Ogden, Utah, USA.

Calabria, L.M., K. Petersen, S.T. Hamman, and R.J. Smith. 2016. Prescribed fire decreases lichen and bryophyte biomass and alters functional group composition in Pacific Northwest prairies. Northwest Science 90: 470-483. doi: 10.3955/046.090.0407

Cochrane, J.F., and P. Delphey. 2002. Status assessment and conservation guidelines: Dakota skipper, Hesperia dacotae (Skinner) (Lepidoptera: Hesperiidae), Iowa, Minnesota, North Dakota, South Dakota, Manitoba and Saskatchewan. US Fish and Wildlife Service, Minneapolis, Minnesota, USA.

Davis, F.W., M.I. Borchert, and D.C. Odion. 1989. Establishment of microscale vegetation pattern in maritime chaparral after fire. Vegetatio 84: 53-67. doi: 10.1007/BF00054665

DeBano, L.F., D.G. Neary, and P.F. Ffolliott. 1998. Fire's effects on ecosystems. John Wiley \& Sons, New York, New York, USA.

Dunwiddie, P.W. 1991. Comparisons of aboveground arthropods in burned, mowed, and untreated sites in sandplain grasslands on Nantucket Island. The American Midland Naturalist 125: 206-212. doi: 10.2307/2426224

Dunwiddie, P.W., R. Davenport, and P. Speaks. 2001. Effects of burning on Castilleja levisecta at Rocky Prairie Natural Area Preserve, Washington: a summary of three long-term studies. Pages 161-172 in: S.H. Reichard, P.W. Dunwiddie, J. Gamon, A.R. Kruckeberg, and D.L. Salstrom, editors. Conservation of Washington's native plants and ecosystems. Washington Native Plant Society, Seattle, Washington, USA.

Fimbel, C. 2004. Habitat enhancement for rare butterflies on Fort Lewis prairies. The Nature Conservancy, Olympia, Washington, USA. 
Hamman, S.T., P.W. Dunwiddie, J.L. Nuckols, and M. McKinley. 2011. Fire as a restoration tool in Pacific Northwest prairies and oak woodlands: challenges, successes, and future directions. Northwest Science 85: 317-328. doi: 10.3955/046.085.0218

Hill, K.H. 2015. Prescribed fire in grassland butterfly habitat: targeting weather and fuel conditions to reduce risk to larvae and enhance post-burn habitat heterogeneity. Thesis, University of Washington, Seattle, USA.

Hoffman, A.A., S.L. Chown, and S. Clusella-Trullas. 2013. Upper thermal limits in terrestrial ectotherms: how constrained are they? Functional Ecology 27: 934-949. doi: 10.1111/j.1365-2435.2012.02036.x

Knapp, E.E., and J.E. Keeley. 2006. Heterogeneity in fire severity within early season and late season prescribed burns in a mixed-conifer forest. International Journal of Wildland Fire 15: 37-45. doi: 10.1071/WF04068

Miller, C., and D.L. Urban. 2000. Connectivity of forest fuels and surface fire regimes. Landscape Ecology 15: 145-154. doi: 10.1023/A:1008181313360

National Interagency Fire Center. 2016. Prescribed fires and acres by agency. <http://www.nifc. gov/fireInfo/fireInfo_stats_prescribed.html>. Accessed 18 September 2016.

National Oceanic and Atmospheric Administration. 2008. Guide to grassland curing observations for national weather Grassland Fire Danger Forecast Indices (GFDI). National Weather Service, Silver Spring, Maryland, USA.

National Wildfire Coordinating Group. 2014. Incident response pocket guide (IRPG). National Wildfire Coordinating Group, Boise, Idaho, USA.

Natural Resources Conservation Service. 2015. Web soil survey. <http://websoilsurvey.nrcs. usda.gov/app/HomePage.htm>. Accessed 1 June 2015.

Neary, D.G., C.C. Klopatek, L.F. DeBano, and P.F. Ffolliott. 1999. Fire effects on belowground sustainability: a review and synthesis. Forest Ecology and Management 122: 51-71. doi: 10.1016/S0378-1127(99)00032-8

New, T.R. 2014. Insects, fire, and conservation. Springer International Publishing, Cham, Switzerland. doi: 10.1007/978-3-319-08096-3

Paquin, P., and D. Coderre. 1997. Deforestation and fire impact on edaphic insect larvae and other macroarthropods. Environmental Entomology 26: 21-30. doi: 10.1093/ee/26.1.21

Pollet, J., and A. Brown. 2007. Fuel moisture sampling guide. Bureau of Land Management, Salt Lake City, Utah, USA.

Rezende, E.L., L.E. Castaneda, and M. Santos. 2014. Tolerance landscapes in thermal ecology. Functional Ecology 28: 799-809. doi: 10.1111/1365-2435.12268

Schultz, C.B., and E.E. Crone. 1998. Burning prairie to restore butterfly habitat: a modeling approach to management tradeoffs for the Fender's blue. Restoration Ecology 6: 244-252. doi: 10.1046/j.1526-100X.1998.00637.x

Schultz, C.B., E. Henry, A. Carleton, T. Hicks, R. Thomas, A. Potter, M. Collins, M. Linders, C. Fimbel, S. Black, H.E. Anderson, G. Diehl, S. Hamman, R. Gilbert, J. Foster, D. Hays, D. Wilderman, R. Davenport, E. Steel, N. Page, P.L. Lilley, J. Heron, N. Kroeker, C. Webb, and B. Reader. 2011. Conservation of prairie-oak butterflies in Oregon, Washington, and British Columbia. Northwest Science 85: 361-388. doi: 10.3955/046.085.0221

Scott, J.H., and R.E. Burgan. 2005. Standard fire behavior fuel models: a comprehensive set for use with Rothermel's surface fire spread model. USDA Forest Service General Technical Report RMRS-GTR-153, Rocky Mountain Research Station, Fort Collins, Colorado, USA. 
Shea, R.W., B.W. Shea, J.B. Kauffman, D.E. Ward, C.I. Haskins, and M.C. Scholes. 1996. Fuel biomass and combustion factors associated with fires in savanna ecosystems of South Africa and Zambia. Journal of Geophysical Research 101: 23 551-23 568. doi: 10.1029/95JD02047

Storm, L., and D. Shebitz. 2006. Evaluating the purpose, extent, and ecological restoration applications of indigenous burning practices in southwestern Washington. Ecological Restoration 24: 256-268. doi: 10.3368/er.24.4.256

Strong, D.J., A.C. Ganguli, and L.T. Vermeire. 2013. Fire effects on basal area, tiller production, and mortality of the $\mathrm{C}_{4}$ bunchgrass, purple threeawn. Fire Ecology 9(3): 89-99. doi: 10.4996/ fireecology.0903089

USDI National Park Service. 2003. Fire monitoring handbook. Fire Management Program Center, National Interagency Fire Center, Boise, Idaho, USA.

Vermeire, L.T., R.B. Mitchell, S.D. Fuhlendorf, and D.B. Wester. 2004. Selective control of rangeland grasshoppers with prescribed fire. Journal of Rangeland Management 57: 29-33. doi: $10.2307 / 4003951$

Warton, D.I., and F.K.C. Hui. 2011. The arcsine is asinine: the analysis of proportions in ecology. Ecology 92: 3-10. doi: 10.1890/10-0340.1

Western Regional Climate Center. 2015. RAWS data. <http://www.wrcc.dri.edu/>. Accessed 18 April 2015.

Wright, B.R., and P.J. Clarke. 2008. Relationships between soil temperatures and properties of fire in feathertop spinifex (Triodia schinzii (Henrard) Lazarides) sandridge desert in central Australia. The Rangeland Journal 30: 317-325. doi: 10.1071/RJ07049

Zuur, A.F., E.N. Ieno, N.J. Walker, A.A. Saveliev, and G.M. Smith. 2009. Mixed effects models and extensions in ecology with R. Springer-Verlag, New York, New York, USA. doi: 10.1007/978-0-387-87458-6 